\title{
GLASGOW UNIVERSITY RADIOCARBON MEASUREMENTS I
}

\author{
M. S. BAXTER, M. ERGIN, and A. WALTON
}

Chemistry Department, The University, Glasgow, W.2.

INTRODUCTION

Two radiocarbon counting systems have been established in the Chemistry Department, University of Glasgow, since late 1967.

The counting gas is methane, at pressures up to $10 \mathrm{~atm}$, and 2 al ternative procedures are followed for methane production, (a) high pressure svnthesis in a stainless steel 4.51 reactor and (b) low pressure synthesis in an all glass flow-reactor. Both systems employ $0.5 \%$ ruthenium on alumina peillets as catalyst (Engelhard Industries Ltd.). Early samples synthesized with Air Products' hydrogen showed evidence of tritium contamination. This gas supply was later replaced with tritium-free hydrogen supplied by Messrs. Griesheim, Düsseldorf, Germany. Both detectors used for routine measurements are 0.51 internal gas counters supplied by Beckman Instruments Inc., California. The detectors are surrounded by a concentric-wall multiple anode anticoincidence counter. The entire counter assembly is encased within a 4-in.-thick lead shield manufactured from aged lead by J. Girdler and Co., London. Counter electronics, anticoincidence system and power supply are of Beckman design (Sharp and Ellis, 1965).

Both detectors have plateaus of length 1000 to 2000 volts with a slope less than $0.5 \%$ per 100 volts. Background count rates at sea level for the 2 detectors are $3.45 \pm 0.10$ and $3.13 \pm 0.10( \pm 2 \sigma)$ counts $/ \mathrm{min}$. at $1 \mathrm{~atm}$ barometric pressure and $5 \mathrm{~atm}$ filling pressure. The variation of background count rate with atmospheric pressure amounts to -0.11 counts $/ \mathrm{cm} . \mathrm{Hg}$ for both detectors. The activity of N.B.S. Oxalic Acid modern standard is $18.76 \pm 0.12$ counts $/ \mathrm{min} .( \pm 2 \sigma)$ in both detectors at $5 \mathrm{~atm}$ pressure at $18^{\circ} \mathrm{C}$, after correction for fractionation and decay.

The basic pretreatment of wood, peat, and charcoal samples consists of visual examination for intrusive rootlets followed by boiling successively in distilled water, $5 \% \mathrm{HCl}$, distilled water, $5 \% \mathrm{NaOH}$, distilled water, $5 \% \mathrm{HCl}$, and distilled water. Shells and marble samples are leached in $5 \% \mathrm{HCl}$ to remove $20 \%$ by weight. Tree seeds, received from the U. K. Forestry Commission, are suitable for analysis without pretreatment.

Methane samples are normally stored for 2 weeks prior to counting to allow for radon decay. This is not essential, however, for most tree seed and spirit samples. A $5 \mathrm{~atm}$ gas fill is routinely employed. Samples are counted at least twice, several days apart, for a minimum of 10,000 counts. Modern standard activities and backgrounds are monitored at least weekly. Mass spectrometric analyses for fractionation correction have been performed at the National Physical Laboratory, Middlesex.

Calculations are based on the Lamont VIII formulae (Radiocarbon, 


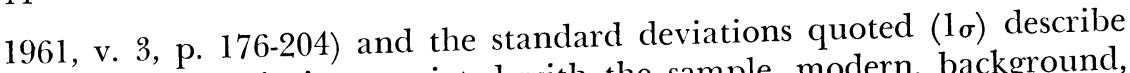
only the uncertainties associated with the sample, modern, background, and mass-spectrometric determinations.

\section{ACKNOWLEDGMENTS}

This work has been supported by a generous grant from the National Environment Research Council for equipment and personnel. Persons and organizations too numerous to list individually have assisted us in the supply of suitable samples and descriptions and to them we offer our gratitude. We acknowledge the cooperation extended to us by the National Physical Laboratory for $\mathrm{C}^{13} / \mathrm{C}^{12}$ measurements and one of us (M.S.B.) thanks the Science Research Council for financial aid.

\section{SAMPLE DESCRIPTIONS}

I. INTERCALIBRATION SAMPLES

Before routine measurement of $\mathrm{C}-14$ activities and ages began a number of samples were requested from various established laboratories for intercalibration purposes.

\section{GU-10. Kilphedir hut circles, Sutherland, Scotland A.D. 42}

$$
1908 \pm 60
$$

Charcoal (Birch-Betula) from hut circle, 1 of 5 in locality just below turf at Kilphedir site, Sutherland, Scotland, $3.5 \mathrm{mi}$ from sea at Helmsdale $\left(58^{\circ} 9^{\prime} \mathrm{N}\right.$ Lat, $3^{\circ} 43^{\prime} \mathrm{W}$ Long). Sample occurred in large pieces 3 to 4 in. across, on living floor and resulted apparently from collapse of conical roof on smouldering hearth. This site, one of few excavated in Scotland, overlies site of earlier dwelling (to be dated). Site was inhabited shortly after change from Sub-Boreal to Sub-Atlantic periods; sample presumably dates end of occupation.

\section{GU-11. Kilphedir hut circles, Sutherland, Scotland $2064 \pm 5$}

Charcoal. Comment: third sample was forwarded to Dr. D. L. Thurber, Lamont Geol. Observatory, Columbia Univ., and dated 2100 \pm 80 (L-1061, unpubl.). Coll. 1965 and subm. by H. Fairhurst, Archaeol. Dept., Univ. of Glasgow.

\section{GU-12. Cardross, Dunbartonshire, Scotland}

Marine shells (mainly Arctica islandica) from marine clayey silt $(\sim \mathrm{ft})$ at junction of laminated basal part and homogeneous upper part, Cardross, Dunbartonshire ( $55^{\circ} 58^{\prime} \mathrm{N}$ Lat, $4{ }^{\circ} 40^{\prime} \mathrm{W}$ Long). Stratigraphic succession represents continuous deposition from subglacial through glaciomarine till and laminated sediments to normal marine clayey silts, produced by thinning of Clyde glacier. Proximal lamination indicated sediments were deposited immediately after ice melted at Cardross. Normal marine deposition followed; adjacent morphology indicates sea level at $+25 \mathrm{~m}$. Coll. 1967 and subm. 1968 by J. Rose, Dept. of Geog., Univ. of Glasgow. Comment (J.G.R.): duplicate sample dated by T. Hamada, Inst. of Phys. and Chem. Research, Bunkyo-Ku, Japan, 
at $11,900 \pm 170$, Ref. N. 475. Recent dates obtained by Sissons (1967), from Loch Lomond I-2235, 11,700 \pm 170 and the upper Forth I-2234, $11,800 \pm 170$ indicate low land in Forth and Clyde basins was submerged $\sim 11,800$ yrs ago. Date agrees with these results.

\section{GU-13. Robert Hill Tree}

$3702 \pm 69$

Wood from Robert Hill Tree previously dated by Birmingham Univ. BIRM-5, $3847 \pm 60$ (Radiocarbon, 1967, v. 9, p. 36) and BIRM-11, $3911 \pm 58$ (Radiocarbon, 1968, v. 10, p. 201). Comment: results agree fairly well and within expectations since parts of the tree were denatured to such an extent as to prevent id. of rings.

\section{GU-14. Redkirk Point, Dumfriesshire}

Peat from Redkirk Point previously BIRM-41, $11,205 \pm$ dated by Birmingham Univ. GU-15. Redk \pm 177 (Radiocarbon, 1968, v. 10, p. 202).

Sample of same $\quad 12,158 \pm 218$ GU-14 and PIRM-41. good and discrepan. Internal agreement between GU-14 and GU-15 is good and discrepancy may be due to sampling difficulties experienced.

\section{ATMOSPHERIC $\mathrm{CO}_{2}$ SAMPLES}

Data reported here are derived from atmospheric $\mathrm{CO}_{2}$ samples coll. at several stations established in both hemispheres in 1967. Sampling points range in lat from $60^{\circ} \mathrm{N}$ to $75^{\circ} \mathrm{S}$ and the following table presents part of conty 6 of 13 stations in operation. Measurements were made as part of continuing study of the transport of $\mathrm{C}^{14}$ within the "dynamic" carbon reservoir and complement the work of other laboratories in this field (Nydal, 1968; Young and Fairhall, 1968; Münnich and Roether, 1967; Olsson et al., 1967; Bien and Suess, 1967; and Rafter, 1965).

$\mathrm{CO}_{2}$ is coll. through exposure of carbonate-free $8 \mathrm{~N} \mathrm{KOH}$ solution supplied to each station by ourselves. Monthly samples are obtained and returned to our laboratories in sealed polythene bottles.

\section{Lerwick series, 1967}

Samples coll. by Meteorological Office in their ventilated East hut, Lerwick $\left(60^{\circ} 08^{\prime} \mathrm{N}\right.$ Lat, $01^{\circ} 11^{\prime} \mathrm{W}$ Long).
GU-16. Lerwick, Scotland $63.7 \pm 0.8 \quad(-23.0) \quad 63.1 \pm 0.8 *$ $\mathrm{CO}_{2}$ coll. Jan. 1967.
GU-17. Lerwick, Scotland $\mathrm{CO}_{2}$ coll. Feb. 1967.
$66.6 \pm 0.8(-23.0) \quad 66.0 \pm 0.9 *$
GU-18. Lerwick, Scotland $\mathrm{CO}_{2}$ coll. March 1967.
$66.2 \pm 0.8(-23.0) \quad 65.6 \pm 0.9 *$
GU.19. Lerwick, Scotland $69.4 \pm 0.9(-23.0) 68.7+1.0 *$ $\mathrm{CO}_{2}$ coll. April 1967. 
GU-20. Lerwick, Scotland $67.7 \pm 0.9 \quad-22.4 \quad 66.9 \pm 0.9 * *$ $\mathrm{CO}_{2}$ coll. July 1967 .

GU-21. Lerwick, Scotland $\quad 80.4 \pm 1.1 \quad-21.5 \quad 79.2 \pm 1.1 * *$ $\mathrm{CO}_{2}$ coll. Oct. 1967.

Comment: in this and some other series mass spectrometric measurements were not available for all samples. A single asterisk indicates that no mass spectrometric measurement was available for the sample; a value of $-23.0 \pm 1 \%$ was assumed. A double asterisk indicates that a mass spectrometric measurement on N.B.S. Oxalic Acid sample was unavailable; a value of $-19.0 \%$ was assumed.

\section{Gibraltar series, 1967}

Samples coll. by Meteorological Office, R.A.F. Gibraltar, in wellventilated room, adjacent to open window $\left(36^{\circ} 09^{\prime} \mathrm{N}\right.$ Lat, $05^{\circ} 21^{\prime} \mathrm{W}$ Long).

\section{GU-22. Gibraltar}

$$
\delta \mathrm{C}^{14 \%} \quad \delta \mathrm{C}^{13 \%} \% \quad \Delta \%
$$

$\mathrm{CO}_{2}$ coll. Jan. 1967.

GU-23. Gibraltar

$$
67.1 \pm 0.8 \quad(-23.0) \quad 66.4 \pm 0.9 *
$$

$\mathrm{CO}_{2}$ coll. April 1967.

\section{GU-24. Gibraltar}

$$
67.2 \pm 0.9 \quad(-23.0) \quad 66.5 \pm 0.9 *
$$

$\mathrm{CO}_{2}$ coll. July 1967.

GU-25. Gibraltar

$$
68.8 \pm 1.2(-23.0) \quad 68.1 \pm 1.3 *
$$$$
99.1 \pm 1.1 \quad-20.4 \quad 97.2 \pm 1.2
$$

$\mathrm{CO}_{2}$ coll. Oct. 1967.

Comment: high value for Oct. 1967 is being investigated further with samples from preceding and following months.

\section{Singapore series, 1967}

Samples coll. by Meteorological Office, R.A.F. Changi, Singapore, at airport $\left(01^{\circ} 22^{\prime} \mathrm{N}\right.$ Lat, $103^{\circ} 59^{\prime} \mathrm{E}$ Long).

$$
\begin{array}{cccc} 
& \delta \mathrm{C}^{14} \% & \delta \mathrm{C}^{13 \%} \% & \Delta \% \\
\text { GU-26. Singapore } & \mathbf{6 4 . 1} \pm \mathbf{0 . 8} & \mathbf{- 2 1 . 9} & \mathbf{6 3 . 1} \pm \mathbf{0 . 9} * * \\
\mathrm{CO}_{2} \text { coll. April } 1967 . & & & \\
\text { GU-27. Singapore } & \mathbf{6 2 . 5} \pm \mathbf{0 . 9} & \mathbf{- 2 2 . 6} & \mathbf{6 1 . 7} \pm \mathbf{1 . 0} * * \\
\mathrm{CO}_{2} \text { coll. July } 1967 . & & & \\
\text { GU-28. Singapore } & \mathbf{6 6 . 4} \pm \mathbf{0 . 9} & \mathbf{- 2 5 . 0} & \mathbf{6 6 . 4} \pm \mathbf{0 . 9} \\
\mathrm{CO} \mathrm{O}_{2} \text { coll. Oct. } 1967 . & & &
\end{array}
$$

\section{Pretoria series, 1967}

Samples coll. by Atomic Energy Board, Pelindaba, Pretoria, in a Stephenson Screen housing a variety of meteorological instruments $\left(25^{\circ}\right.$ $45^{\prime}$ S Lat, $28^{\circ} 16^{\prime}$ E Long).

\section{GU-29. Pretoria $\mathrm{CO}_{2}$ coll. Jan. 1967.} $\delta \mathrm{C}^{1+\%} \quad \delta \mathrm{C}^{13 \%} \%$ $\Delta \%$ 
GU-30. Pretoria

$\mathrm{CO}_{2}$ coll. April 1967.

$$
60.5 \pm 0.8 \quad-24.3 \quad 60.3 \pm 0.9 * *
$$

GU-31. Pretoria

$\mathrm{CO}_{2}$ coll. July 1967.

$$
58.4 \pm 1.0 \quad-24.1 \quad 58.1 \pm 1.1
$$

GU-32. Pretoria

CO.2 coll. Oct. 1967.

$$
65.8 \pm 0.9-23.5 \quad 65.3 \pm 0.9
$$

\section{Stanley, Falkland Islands series, 1967}

Samples coll. outcloors by Meteorological Office, Stanley, Falkland Is., in meteorological thermometer screen $\left(51^{\circ} 42^{\prime} \mathrm{S}\right.$ Lat, $57^{\circ} 52^{\prime} \mathrm{W}$
Long).

\section{GU-33. Stanley}

CO., coll. A pril 1967.

GU.34. Stanley

$\mathrm{CO}_{2}$ coll. July 1967.

\section{GU-35. Stanley}

CO.. coll. Oct. 1967.

$$
\begin{array}{ccc}
\delta \mathrm{C}^{14} \% & \delta \mathrm{C}^{13} \% & \Delta \% \\
\mathbf{5 9 . 4} \pm \mathbf{0 . 8} & -\mathbf{2 4 . 1} & \mathbf{5 9 . 1} \pm \mathbf{0 . 9} \\
& & \\
\mathbf{5 7 . 5} \pm \mathbf{0 . 8} & -\mathbf{2 4 . 0} & \mathbf{5 7 . 1} \pm \mathbf{0 . 9} \\
& & \\
\mathbf{5 6 . 1} \pm \mathbf{0 . 8} & -\mathbf{2 3 . 0} & \mathbf{5 5 . 5} \pm \mathbf{0 . 9}
\end{array}
$$

\section{Halley Bay series, 1967}

Samples coll. by British Antarctic Survey in one of their instrument huts (75० $31^{\prime}$ S Lat, $26^{\circ} 45^{\prime} \mathrm{W}$ Long).

$$
\begin{aligned}
& \text { GU-36. Halley Bay } \\
& \delta \mathrm{C}^{14 \%} \% \quad \delta \mathrm{C}^{13 \%} \% \\
& \mathrm{CO}_{2,} \text { coll. April } 1967 . \\
& 60.2 \pm 1.2 \quad-18.4 \quad 58.1 \pm 1.2 \\
& \text { GU-37. Halley Bay } \\
& \text { CO. coll. July } 1967 . \\
& 58.9 \pm 0.9 \quad-19.3 \quad 57.0 \pm 1.0 \\
& \text { GU-38. Halley Bay } \\
& \text { CO. coll. Oct. } 1967 . \\
& 58.4 \pm 0.8 \quad-19.5 \quad 56.6 \pm 0.9
\end{aligned}
$$

\section{SPIRIT SAMPLES}

An attempt has been made to establish atmospheric $\mathrm{C}^{14}$ concentrations in Scotland in past yrs. A series of malt whisky samples have been analyzed for the period 1933-1966. A good correlation exists between atmospheric $\mathrm{C}^{14}$ concentrations and those in the spirit samples for recent times and thus we have considerable confidence in the application of this material to studies of past atmospheric $\mathrm{C}^{14}$ fluctuations in this region.

\footnotetext{
GU-39. Malt whisky, Scotland,$$
\delta \mathrm{C}^{14} \% \quad \delta \mathrm{C}^{13 \%} \% \quad \quad \Delta \%
$$$$
1933
$$

Barley coll. 1933, distilled 1934.
} 
GU-40. Malt whisky, Scotland, 1937 $-1.5 \pm 0.6(-26.5)-1.2 \pm 0.6 * *$ Barley coll. 1937, distilled 1938.

GU-41. Malt whisky, Scotland, 1941 $-3.0 \pm 0.7 \quad-26.6 \quad-2.7 \pm 0.7$ Barley coll. 1941, distilled 1942.

GU.42. Malt whisky, Scotland, 1945 $-4.6 \pm 0.7-22.8 \quad-4.8 \pm 0.7 * *$ Barley coll. 1945, distilled 1946.

GU-43. Malt whisky, Scotland, 1949 $-3.2 \pm 0.7 \quad-24.0 \quad-3.4 \pm 0.7 * *$ Barley coll. 1949, distilled 1950.

GU-44. Malt whisky, Scotland, 1951

$$
-3.0 \pm 0.6 \quad-29.5 \quad-2.1 \pm 0.6
$$

Barley coll. 1951, distilled 1952.

GU-45. Malt whisky, Scotland, 1957

$$
6.5 \pm 0.7 \quad-25.1 \quad 6.5 \pm 0.7 * *
$$

Barley coll. 1957, distilled 1958.

GU-46. Malt whisky, Scotland, 1958
$12.3 \pm 0.7 \quad-28.2 \quad 12.9 \pm 0.7$

Barley coll. 1958, distilled 1959.

GU-47. Malt whisky, Scotland, 1960

$$
20.1 \pm 0.7 \quad-27.9 \quad 20.8 \pm 0.8
$$

Barley coll. 1960, distilled 1961.

GU-48. Malt whisky, Scotland, 1962

$39.1 \pm 0.8 \quad-24.9 \quad 39.1 \pm 0.8 * *$ Barley coll. 1962, distilled 1963.

GU-49. Malt whisky, Scotland, 1963

$$
86.1 \pm 1.1(-26.5) \quad 86.6 \pm 1.1
$$

Barley coll. 1963, distilled 1964.

GU-50. Malt whisky, Scotland, 1964

$87.7 \pm 1.0 \quad-30.0 \quad 89.5 \pm 1.0$

Barley coll. 1964, distilled 1965.

GU-51. Malt whisky, Scotland, 1965

$76.0 \pm 1.2 \quad-29.0 \quad 77.4 \pm 1.3$

Barley coll. 1965, distilled 1966. 
GU-52. Malt whisky, Scotland,
1966

$$
68.3 \pm 1.2 \quad-29.5 \quad 69.8 \pm 1.3
$$

Barley coll. 1966, distilled 1967.

Comment: several other samples of malt and blended whisky have been analyzed at the National Physical Laboratory, Teddington and discussed by Walton et al. (1967). As shown in fig. 1, results of this series agree well with data on Danish cereals reported by Tauber (1967). Small discrepancies may be attributable to slightly different growth periods of the each yr when and Glasgow samples. The former were coll. on July 1st of August/Septem barley for whisky manufacture is harvested during curately the atmor. Results indicate materials of plant origin reflect accurately the atmospheric $\mathrm{C}^{14}$ concentrations prevalent during growth.

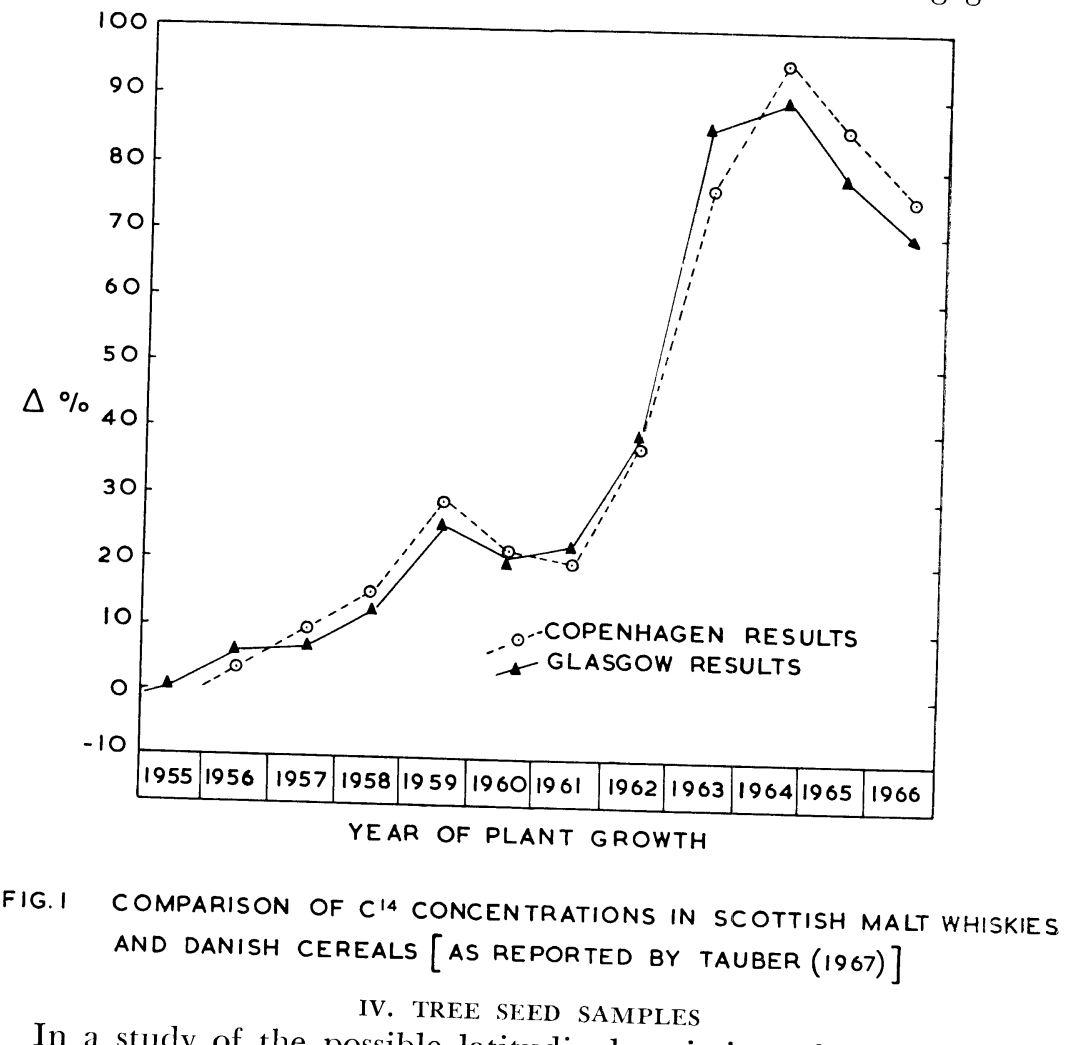

In a study of the possible latitudinal variation of atmospheric $\mathrm{C}^{14}$ concentrations a number of tree seeds (subm. and id. by U. K. Forestry Commission) have been analyzed. The seeds, stored in vacuum since collection, represent a variety of species.

$$
\begin{array}{ccc}
\delta \mathrm{C}^{14} \% & \delta \mathrm{C}^{13} \% & \Delta_{\%} \\
\mathbf{7 2 . 8} \pm \mathbf{1 . 0} & \mathbf{- 2 6 . 8} & \mathbf{7 3 . 5} \pm \mathbf{1 . 0} * *
\end{array}
$$
W Long). 
GU-54. Alaska, U.S.A.

$\mathbf{7 3 . 7} \pm \mathbf{1 . 2}-\mathbf{2 8 . 4} \quad \mathbf{7 4 . 9} \pm \mathbf{1 . 3}$

Seeds (pinus contorta) coll. 1965 from Alaska $\left(56^{\circ} 50^{\prime} \mathrm{N}\right.$ Lat, $155^{\circ}$ W Long).

GU-55. NW England

$77.3 \pm 0.9 \quad-31.6 \quad 79.6 \pm 1.0 * *$

Seeds (pinus syluestris) coll. 1965 from NW England (54 $\mathrm{N}$ Lat, $2^{\circ}$ $30^{\prime}$ W Long).

GU.56. Campine, Belgium $\quad 79.2 \pm 1.3(-28.0) \quad 80.3 \pm 1.4 * *$ Seeds (alnus glutinosa) coll. 1965 from Campaine, Belgium $\left(51^{\circ} \mathrm{N}\right.$ Lat, $5^{\circ} \mathrm{E}$ Long).

GU.57. SE England

$76.8 \pm 1.0 \quad-26.8 \quad 77.5 \pm 1.0 * *$ Seeds (pinus syluestris) coll. 1965 from SE England $\left(51^{\circ} \mathrm{N}\right.$ Lat, $0^{\circ}$ 30 ' W Long).

\section{GU.58. Homburg, Germany $\quad \mathbf{7 5 . 6} \pm 1.2 \quad-28.1 \quad 76.9 \pm 1.3$}

Seeds (larix decidua) coll. 1965 from Homburg, Germany $\left(50^{\circ} \mathrm{N}\right.$ Lat, $8 \circ 30^{\prime}$ E Long).

\section{GU-59. British Columbia,}

\section{Canada}

$\mathbf{7 3 . 6} \pm \mathbf{0 . 9}-\mathbf{2 6 . 8} \quad \mathbf{7 4 . 3} \pm \mathbf{1 . 0}$

Seeds (pinus contorta) coll. 1965 from British Columbia $\left(50^{\circ} \mathrm{N}\right.$ Lat, $125^{\circ}$ W Long).

GU-60. Styria, Austria $\quad 73.9 \pm 1.3(-\mathbf{2 8 . 0}) \quad \mathbf{7 4 . 9} \pm 1.3 * *$ Long).

Seeds (larix decidua) coll. 1965 from Styria $\left(47^{\circ} 30^{\prime} \mathrm{N}\right.$ Lat, $15^{\circ} \mathrm{E}$

GU-61. Washington, U.S.A. $76.7 \pm 0.9(-28.0) \quad 77.7 \pm 1.0 * *$ Seeds (picea sitchensis) coll. 1965 from Washington $\left(46^{\circ} 40^{\prime} \mathrm{N}\right.$ Lat, $120^{\circ}$ W Long).

GU-62. Oregon, U.S.A.

$$
\mathbf{7 7 . 5} \pm \mathbf{1 . 0}(-\mathbf{2 8 . 0}) \quad \mathbf{7 8 . 6} \pm \mathbf{1 . 0} * *
$$

Seeds (abics amabalis) coll. 1965 from Oregon $\left(45^{\circ} \mathrm{N}\right.$ Lat, $120^{\circ} \mathrm{W}$ Long).

GU-63. Nagano, Japan

$\mathbf{7 5 . 9} \pm 1.2(-28.0) \quad 76.9 \pm 1.2 * *$

Seeds (larix leptopolis) coll. 1965 from Nagano $\left(36^{\circ} \mathrm{N}\right.$ Lat, $138^{\circ} \mathrm{E}$ Long).

General Comment: $\mathrm{C}^{14}$ activities scatter outside the statistical error and indicate disequilibrium in $\mathrm{N}$ lats. These fluctuations may reflect injections of stratospheric $\mathrm{C}^{14}$ into troposphere at preferred lats although local Suess effects cannot be ignored in industrial areas.

GU-64. Newbie Cottages, Solway Firth

Peat at base of low cliff on $\mathrm{N}$ shore of Solway Firth, $50 \mathrm{~m} \mathrm{~W}$ of W angle of Newbie Cottages, Dumfriesshire, Scotland, Nat. Grid. Ref. NY 
167649 (54 $58^{\prime} \mathrm{N}$ Lat, $3^{\circ} 18^{\prime} \mathrm{W}$ Long). Sample is top $5 \mathrm{~cm}$ of peat bed $12.5 \mathrm{~cm}$ thick underlain by fluvio-glacial sands and gravels, overlain by Carse Deposits. Top of peat bed is at $5.79 \mathrm{~m}$ above Ordnance Datum (Newlyn). Coll. 1965 and subm. by W. G. Jardine, Dept. of Geol., Univ. of Glasgow. Comment (W.G.J.): date is younger than that of (Q-637) $8135 \pm 150$ yrs в.P. (Godwin and Willis, 1952) for wood from tree stump in situ in peat bed at Redkirk Point, $11 \mathrm{~km} \mathrm{E}$ of Newbie Cottages. Both sites are on present shore of Solway Firth, but older peat, at Redkirk Point, occurs ca. $3 \mathrm{~m}$ lower than peat in Newbie Cottages.

\section{GU.65. Sandyknowe Bridge, Lochar Water}

$7426 \pm 136$

Wood fragments from borehole on W bank, Lochar Water, S side Dumfries/Lockerbie Rd., A 709, Dumfriesshire, Scotland, Nat. Grid. Ref. NY $017776\left(55^{\circ} 5^{\prime}\right.$ N Lat, $3 \circ 32^{\prime}$ W Long). Sample immediately above junction of silty fine sand (local representative of Carse Deposits) Datum (New flavio-glacial sands and gravels, at $0.58 \mathrm{~m}$ above Ordnance Solway Firth. Coll. 1965 by Geotechnical from present $\mathrm{N}$ shore of subm. by W. G. Jardine Comment (W.G. and Concrete Services Ltd; Flandrian marine tinns. Cote indicates beginning of date GU-64 and transgression at site; it agrees closely with previous neous a neous along present $\mathrm{N}$ shoreline of Solway Firth and within large elongate embayment, to SE of Dumfries, now covered by Lochar Moss.

\section{GU-66. Carlisle Castle mortar}

Mortar from "De Ireby's Tower" $\mathbf{5 2}$ в.c. $55^{\prime}$ W Long). Sample taken from trance, $9.5 \mathrm{ft}$ from ground level, $2 \mathrm{ft}$ foor $W$ room, Garderobe Enabove lower side of above lower side of stone lintel. Coll. and subm. 1967 by Ministry of true a Buildings and Works, Ancient Monuments Branch. Comment: carbon is evident.
trus contamination by considerable quantity of old

Date lists:

\section{REFERFNCES}

$\begin{array}{ll}\text { Birmingham I } & \begin{array}{l}\text { Shotton, Blundell, and Williams, 1967 } \\ \text { Birmingham II }\end{array} \\ \text { Shotton, Blundell, and Williams, 1968 } \\ \text { Cambridge V } & \text { Godwin and Willis, 1962 } \\ \text { Copenhagen VIII } & \begin{array}{l}\text { Tauber, 1967 } \\ \text { Lamont VIII }\end{array} \\ \text { Broecker and Olson, 1961 }\end{array}$

Bien, G. and Suess, H., 1967, Transfer and exchange of carbon-14 between the atmosDating and Broecker, W. S. and Olson Low-Level Counting, I.A.E.A., Vienna, p. 105-115. Radiocarbon, v. 3, p. 176-204. A., 1961, Lamont radiocarbon measurements VIII: Godwin, $\mathrm{H}$ and Willis, $\mathrm{E}$. urements V: Radiocarbon, v. 4, p. 57-70. Münnich, K O and Roether, W. P. 57-70. atmosphere to the ocean: Int 1967, Transfer of bomb C-14 and tritium from the and C-14 profiles: Symposium on Rading of the ocean and the basis of tritium Counting, I.A.E.A., Vienna, p. 93-104. 
Nydal, R. 1968, Further investigation on the transfer of radiocarbon in nature: Jour. Geophys. Research, v. 73, p. 3617-3635.

Olsson, I. U., Karlén, I., and Stenberg, A., 1966, Radiocarbon variations in the atmosphere: Tellus, v. 18, p. 293.

Re $\mathrm{T}$. 1965 . Increase in the $\mathrm{C}^{14}$ activity in the atmosphere of the southern hemisphere from the testing of nuclear weapons: New Zealand Jour. Sci. and Technology, v. 8, p. 472

Sharp, R. A and Ellis, J. G., 1965, System design in low background internal gas sample counting of carbon-14 and tritium: Proc. Inter. Conf. on Radiocarbon sample counting of carbon-14 and Washington, U.S.A., p. 17-28. and Tritium Dating, 6th, Pullman, Washington, U. G., 1967, Birmingham University

Shotton, F. W., Blundell, D. J., and Williams, R.

radiocarbon dates I: Radiocarbon, W. 9, p. $35-37$. . G., 1968, Birmingham University Shotton, F. W., Blundell, D. J., and Wriocarbon, v. 10, no. 2, p. 200-206. radiocarbon dates II: Radiocarbon, v. 10, no. 2, p. $200-206$.

Sissons, J. B., 1967, G19

ogy, v. 3, p. 375-381.

Tauber, Henrik, 1967, Copenhagen radiocarbon menc v. 9, p. 246-256. tions in atmospheric $\mathrm{C}^{14}$ activity: Radiocarbon, v. 9, p. 246-256. Young, J. A. and Fairhall, A. W., 1968, Ra Geophys. Research, v. 73, p. 1185-1200.

Walton, A., Baxter, M. S., Callow, W. J., and Baker, M. J., fluctuations: Symposium on tions in environmental materials and Low-Level Counting, I.A.E.A., Vienna, p. 41. 47 . 